\title{
There Are No "Other" Species: \\ Confessions of a Biology Heretic
}

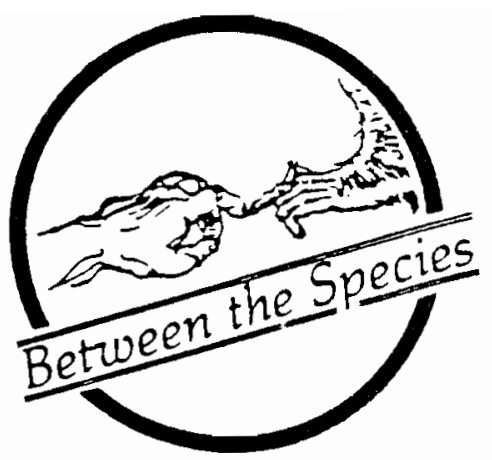

\author{
Dr. Michael W. Fox \\ The Humane Society of the Urited States \\ Washington, D.C.
}

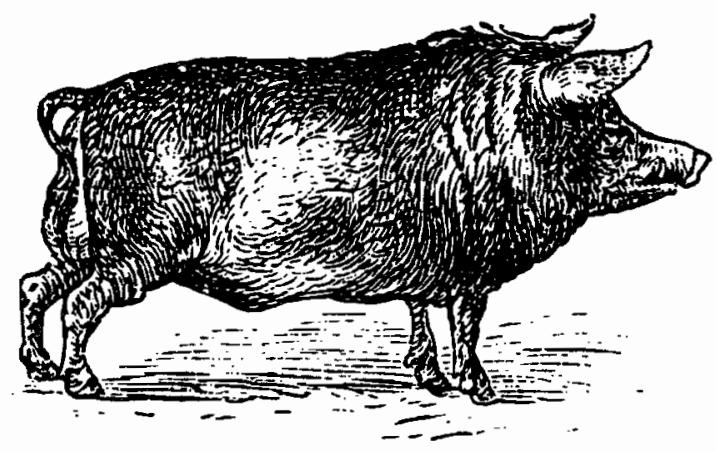

of industrial society. But we should all ponder the possibility that this claim is half right. After all, we are all part of the one life of the Earth's creation and ecology. The hierarchical order of biology and evolutionary theory that places humans over all, has contributed significantly to the worldwide ecological and social disorder that we face today.

Perhaps a new world order might evolve to further the goals of global peace, justice and the integrity of Creation, if we were to balance the realization that there are many species on Earth other than human, of unique intrinsic value, with the fact that we are all part of the one life and of the Earth's ecosystem. Then the linear, hierarchic notion of human superiority and separateness from the rest of creation might be seen as a grand delusion: an illusion with no factual basis compared to the eccentric, yet paradoxically eco-centric view that species are not separate from each other biologically or ecologically. That human genes can be incorporated into the genetic structure of pigs and plants, attests to our biological kinship with all life. When humankind once again begins to see beyond all distinctions and the falsehoods of dualistic perception, we might enjoy a new world order that is truly democratic for the benefit of all future generations who are to inherit the Earth.

Nowhere more clearly do we find the hierarchical, linear world-order in evidence than in industrial agriculture. It is the antithesis of the more holistic them feel that there is no distance and thus little difference between themselves and the cats and dogs and other creatures they live with. This attitude, which makes us feel a sense of kinship with fellow creatures, was evident in earlier times when our ancestors were gatherer-hunters, and at a later time when sustainable, subsistence farming communities were established.

To claim that there are no other species is heretical, not only to the biological sciences but to the status quo 
(whole and integrated systems) approach to food production as exemplified by the sustainable and ecologically sound principles of organic/natural farming. Industrial agriculture condones the cruel practices of "factory" farming livestock and poultry; the wholesale applications of harmful chemical fertilizers and pesticides to monoculture crops; and the "mining" of the soil and underlying aquifers to produce "commodity" crops, primarily to feed livestock and poultry. Industrial agriculture is so inefficient, so wasteful of finite resources, and so dependent upon costly chemical and pharmaceutical and genetically engineered "inputs." Yet it is a system condoned by those whose world view is dualistic, exploitive, adversarial and ultimately destructive. It is illustrative of the harmful consequences of adhering to the beliefs that might makes right; that the ends justify the means; and that the rest of Creation was made primarily for man's use, to the degree that on the grounds of necessity, predicated by the purported social good of illimitable economic growth, we may, in all good conscience, vanquish the world and exterminate other life forms in the name of "progress," "natural" evolution, and even "God's will."

This world view, the view that makes such distinctions as to perceive other species as separate and even inferior, is in power today. But it is a world view that we must all challenge and change, because in the final analysis, it is a half-truth; a deceptive way of structuring reality, and a destructive way of living.

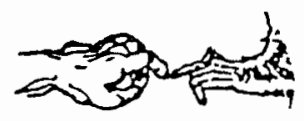

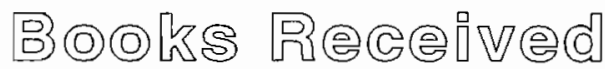

Greta Gaard, ed.

ECOFEMINISM

Women, Animals, Nature

Philadelphia: Temple University Press, 1993

preface, $314 \mathrm{p}$, selected bibliography, index

$\$ 44.95$ cloth, $\$ 18.95$ paper

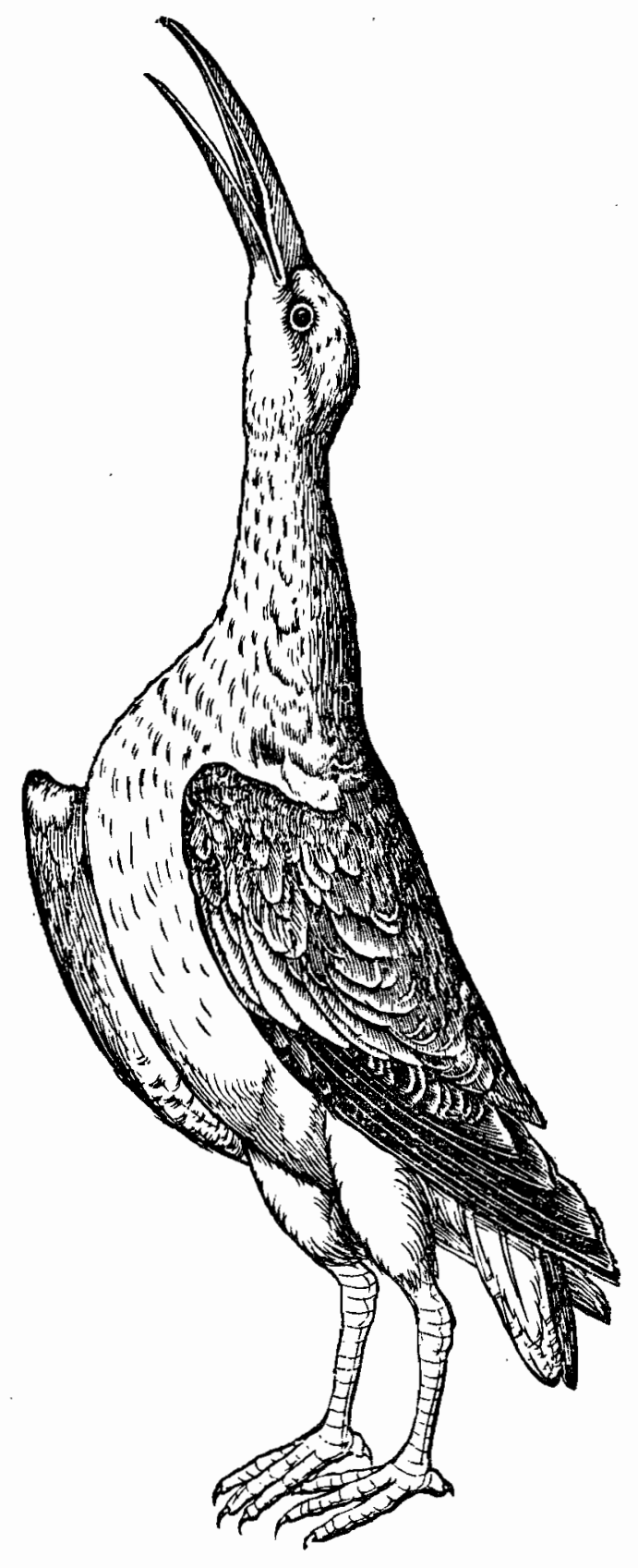

